\title{
イオンプレーティングで作製したTi-N皮膜の 残留応力に及ぼす皮膜組成の影響
}

\author{
西田典秀*，岡田光正 ${ }^{* *}$ ，本田和男 ${ }^{* * *}$ ，川崎仁士*，細川智生 ${ }^{* * * *}$
}

\author{
Effects of Film Composition on Residual Stress in Ti-N Films Prepared by Ion Plating
}

\author{
Norihide NISHIDA* , Mitsumasa OKADA**, Kazuo HONDA***, \\ Hitoshi KAWASAKI* and Norio HOSOKAWA ${ }^{* \cdots *}$
}

\begin{abstract}
Ti-N films of various compositions ( $\mathrm{N} / \mathrm{Ti}$ ratios of $1.09 \sim 0.41$, oxygen contents of $0.8 \sim 6.5$ at $\%$, and carbon contents of $5.7 \sim 9.4$ at\%) were prepared by ion plating onto silicon wafers, and the residual stresses of the films were investigated. In TiN single-phase films, the compressive stress reached a maximum at an $\mathrm{N} / \mathrm{Ti}$ ratio of 1.0 , and decreased as the $\mathrm{N} / \mathrm{Ti}$ ratio increased or decreased of 1.0 . At N/Ti ratios lower than 0.8 , compressive stress again began to increase as $\mathrm{Ti}_{2} \mathrm{~N}$ phase was deposited in the TiN, but decreased as $\alpha-\mathrm{Ti}$ phase appeared in the films. At an $\mathrm{N} / \mathrm{Ti}$ ratio of 0.41 , the film consisted of $\mathrm{Ti}_{2} \mathrm{~N}$ and $\alpha$ - $\mathrm{Ti}$, and the residual stress in the film was tensile. Compressive stress increased with increasing oxygen or carbon contents of the film.
\end{abstract}

Key Words : Ti-N Film, Ion-Plating, Residual Stress, Film Composition

\section{1. 粕言}

イオンプレーティングやスパッタ等で作製したTiN皮 膜に発生する残留応力については, 既にいくつかの検討 がなされており, 数GPaオーダーの圧縮残留応力の存

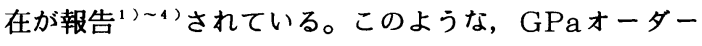
の圧縮残留応力の発生はTiN以外の化合物 ${ }^{5)}$ や金属皮膜 においてあみられ ${ }^{6)}$ ，プラズマを利用した気相成長膜の 特長とあ考えられる。

圧縮応力の発生原因としては, 皮膜形成時における皮 膜の体積膨張が考えられており, 通常ガス原子のピーニ ング効果 ${ }^{7}$ によるあのとして理解されている。TiN皮膜 においても, 化学量論値を越えた過剰の窒素原子の取り 込みや ${ }^{1)}$, 皮膜中への格子間原子としての室素イオンの 打ち込み ${ }^{2)}$ に基づく皮膜体積の膨張などの機構が推測さ れている。このようにTiN皮膜の残留応力の発生には皮 膜中に導入される窒素原子が大きく関わっているものと 考えられており, 皮膜中の窒素濃度は皮膜の残留応力に 影传を及ぼす重要な因子の一つと考えられる。しかし,

* 岡山県工業技術センター（テ701-01 岡山県岡山市今保 661-1)

Ind. Tech. Center of Okayama Pref. (661-1, Imaho, Okayama-shi, Okayama 701-01)

** 岡山大学大学院（宁700 岡山県岡山市津島中）

Graduate School, Okayama Univ. (Tsushimanaka, Okayama-shi, Okayama 700)

*** 岡山大学工学部 (テ700 岡山県岡山市津島中)

Fac. of Eng., Okayama Univ. (Tsushimanaka, Okayama-shi, Okayama 700)

**** 岡山理科大学 (下700 岡山県岡山市理大町)

Okayama College of Science (Ridai-cho, Okayamashi, Okayama 700)
従来の報告には，このような視点から皮膜組成を考察し た系統的な検討はほとんどなされていないように思われ る。そこで本報告では，イオンプレーティングによる TiN皮膜の残留応力の発生挙動を理解する目的で, 残留 応力に及ぼす皮膜組成（N/Ti比, 酸素・炭素の添加） の影響を検討した。

\section{2. 実験方法}

\section{1 皮膜の作製}

$\mathrm{N} / \mathrm{Ti}$ 比の異なる皮膜の作製は既報 ${ }^{8)}$ に従い, rf 電力 $600 \mathrm{~W}$, バイアス電圧 $-200 \mathrm{~V}$, 基板温度 $773 \mathrm{~K}$ で行った。 また, 公素ガス中に一部酸素ガス, あしくはメタンガス を導入し, 酸素及び炭素濃度の異なる皮膜も作製した。 皮膜の組成分析は, X線マイクロアナライザー（EPM A)を用い ${ }^{9)}, \mathrm{N} / \mathrm{Ti}$ 比 $=\mathrm{N}$ at\% / Ti at\%で組成比を計 算した。窒素の標準試料には窒素濃度既知のTiN・イオ ンプレーティング膜 ${ }^{8)}$ ， そして酸素と炭素の標準試料に は $\mathrm{TiO}_{2}$ ならびに炭素を用いた。

基板には（111）に配向した市販のシリコンウェハ （50.8mm径， $0.5 \mathrm{~mm}$ 厚）を用いた。基板はシースヒー ターで加熱した銅のブロックに固定し，基板温度の測定 は銅ブロックに挿入したC-A熱電対で行った。膜厚の 測定は走查型電子顕微鏡（SEM）による断面観察すしく は表面粗さ計（㑣東京精密製surcom 1500A）による段 差測定によった。

\section{2 残留応力の测定}

皮膜の残留応力はGlang らの方法 ${ }^{10)}$ (触針法) に従い 室温での基板の変形量より算出した。

基板の変形量はウェハの曲率の変化より求めた。ウェ 


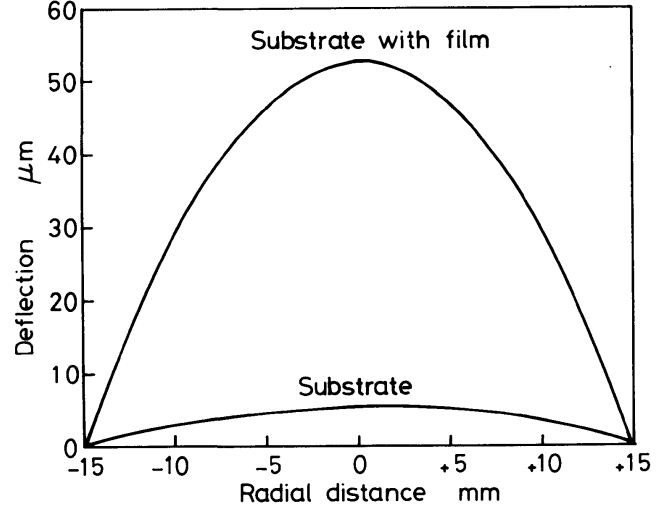

Fig. 1 Microstylus profiles across a silicon wafer substrate with and without a TiN film $(\mathrm{N} / \mathrm{Ti}$ ratio $=0.91$, thickness $=2.4 \mu \mathrm{m}$ ).

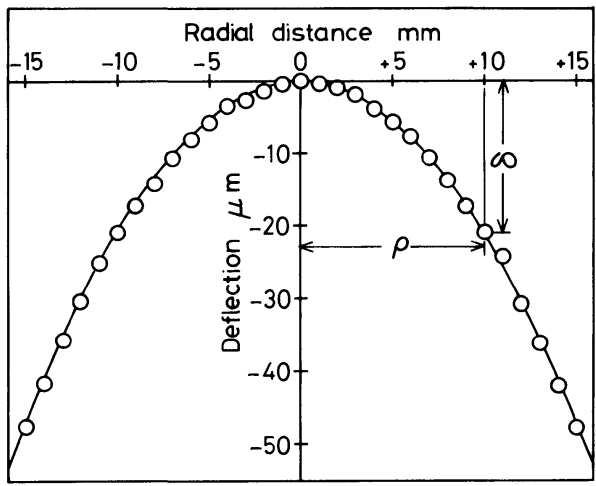

Fig. 2 Parabolic deflection of a silicon wafer caused by residual stress in $\mathrm{TiN}$ film $(\mathrm{N} / \mathrm{Ti}$ ratio $=0.91$, thickness $=2.4 \mu \mathrm{m}$ ).

八の曲率の測定は表面粗さ計を用い, 半径方向の表面プ ロファイルをとることにより行った。また，ウェハは固 有の曲率を有しているため, 蒸着前と蒸着後の曲率を測 定し（図 1), 両者の差をとることにより成膜による変 形量 $\delta$ を求めた。そして，図 2 に示すように，中心から の距離 $\rho$ と $\delta$ の測定値を放物線近似し， $\delta / \rho^{2}$ を求め, 次式により応力値を算出した。

$$
\sigma=\frac{E}{3(1-\nu)} \cdot \frac{t_{\mathrm{s}}^{2}}{t_{\mathrm{f}}} \cdot \frac{\delta}{\rho^{2}}
$$

ここで, $E$ とレは基板のヤング率とポアンン比（Si (111) : $\left.(1-\nu) / E=4.338 \times 10^{-12} \mathrm{~Pa}^{-1}\right)^{11)}$ で， $t_{\mathrm{s}}$ と $t_{\mathrm{f}}$ は それぞれ基板ならびに皮膜の厚さを示す。

\section{3. 結果及び考察}

\section{1 残留応力値に及ぼす皮膜厚さの粕雷}

化学量論組成（N/Ti比=1）に近い皮膜が形成され る条件下で作製した膜厚0.07から3. $4 \mu \mathrm{m}$ の皮膜の残留 応力の変化を図 3 に示す。残留応力値はすべての膜厚で

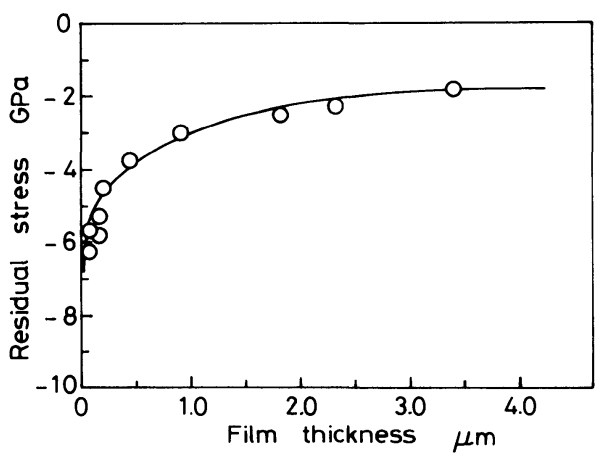

Fig. 3 Relation between residual stress in $\mathrm{TiN}$ film (N/Ti ratio $\leftrightharpoons 1$ ) and film thickness.
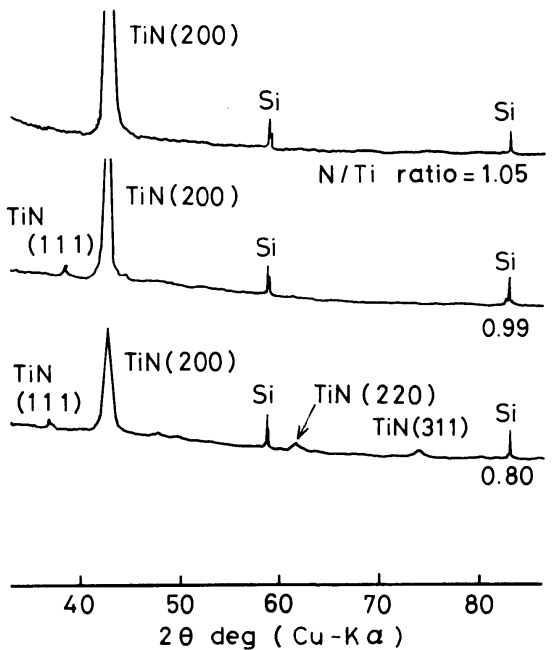

Fig. 4 X-ray diffraction patterns of $\delta$-phase TiN films of various $\mathrm{N} / \mathrm{Ti}$ ratios.

圧縮を示し，膜厚が小さくなるほど大きくなった。とく にその変化は膜厚 $1 \mu \mathrm{m}$ 以下で大きく, 膜厚 $0.07 \mu \mathrm{m} て ゙$ -6.3GPaであり, $0.9 \mu \mathrm{m}$ で-2.9GPaの值を示した。 一方 $1 \mu \mathrm{m}$ 以上での変化は小さく, 膜厚 $0.9 \mu \mathrm{m}$ で-2.9 $\mathrm{GPa}, 3.4 \mu \mathrm{m}$ でー1.8GPaを示した。

このように, 膜厚が小さい皮膜で残留応力値が大きく なるのは, 膜厚の小さい段階では基板の影響が大きく現 れ，歪みが大きくなっていることを示唆しているすのと 推測される。以上の結果より，以下の実験では残留応力 值に及ぼす膜厚の影響を考虑して，膜厚を 1.8 から 2.8 $\mu \mathrm{m}$ の範囲とした。

\section{2 TiN単相域における残留応力}

N/Ti比の変化によって皮膜の相組成が変化し，X線 回折の結果からN/Ti比が 1 前後から0.8 前後で, TiN単

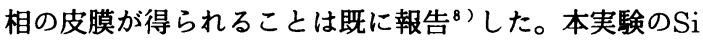
基板においてあ同様の結果が得られ，図 4 に示すように $\mathrm{N} / \mathrm{Ti}$ 比 $=1.1 \sim 0.8$ の皮膜で (200)に配向したTiN単相の 


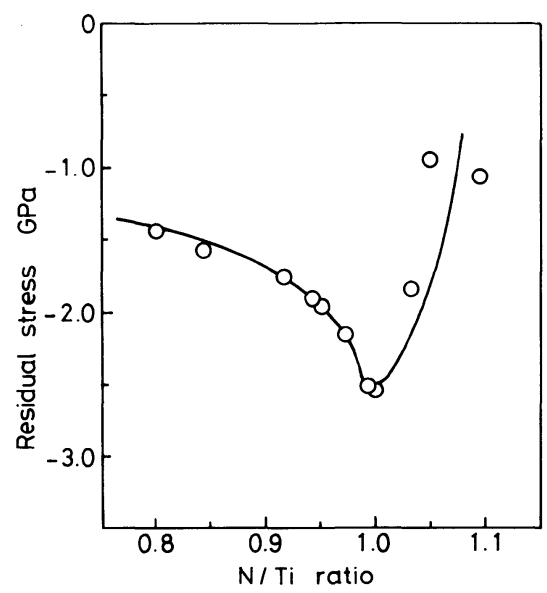

Fig. 5 Effect of $\mathrm{N} / \mathrm{Ti}$ ratio on residual stress in $\delta$-phase TiN film.

回折図形が得られた。

図 5 に，TiN単相域での皮膜の残留応力の変化を示す。 残留応力はN/Ti比によって変化がみられ，化学量論組 成 $(\mathrm{N} / \mathrm{Ti}$ 比 = 1) に近い皮膜で最大値 $-2.5 \mathrm{GPa}$ を示 し，N/Ti比が 1 より増加ならびに減少しても, 残留応 力は減少した。化学量論組成からのずれによる残留応力 の減少の程度は, N/Ti比が 1 以下ではN/Ti比 $=1.0$ 0.8 範囲で-2.5から-1.4GPa程度と比較的小さいが, $\mathrm{N} / \mathrm{Ti}$ 比が 1 以上ではN/Ti比 $=1.0 \sim 1.09$ の範囲で残留 応力は -2.5 から $-0.9 \mathrm{GPa}$ と大きい。これはバルク材 のTiNのN/Ti比による格子定数の变化 $\left.{ }^{12}\right)$ 之類似の傾向 を示しており, 残留応力値にTiNの格子定数の変化が関 与していることを示唆している。

イオンプレーティングによる窒化物皮膜形成において, 窒化物が形成される場所は放電空間よりむしろ基板上で あることを示す結果が報告されている(13)，14)。TiN皮膜 の圧縮残留応力発生においても，TiNとして形成された 状態で基板上に堆積するのならば，皮膜の体積膨張や残 留応力の組成依存性を説明することは困難と思われ，基 板上で皮膜の体積膨張につながるような過程が生じてい るすのと考えられる。このような皮膜の体積膨張を生じ る機構として，TiNを形成するための窒素原子がイオン の打ち込み ${ }^{2)}$ 等, なんらかの形で結晶格子中に取り込ま れていると考えることは妥当なことと思われる。しかし 図 5 によると，N/Ti比が 1 以上ではむしろ残留応力は 減少しており, 化学量論値を越えた過剩の窒素の取り込 み'が圧縮残留応力発生の主原因ではないことを示して いる。

以上のように, 残留応力の発生を皮膜の体積膨張に求 める場合, 皮膜の体積を規定する要因の一つが格子定数 であることを考えれば，图 5 に示す残留応力の変化がバ ルク材の格子定数の変化 ${ }^{12)}$ と類似することは当然であろ
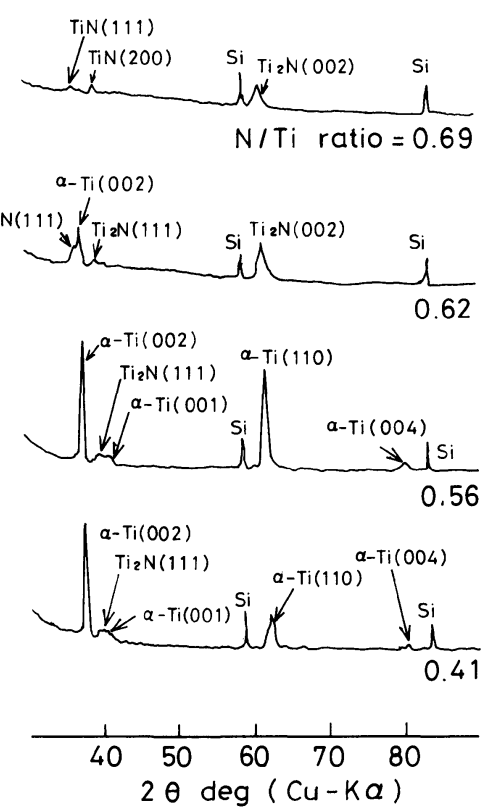

Fig. 6 X-ray diffraction patterns of Ti-N films containing $\mathrm{Ti}_{2} \mathrm{~N}$ and $\alpha-\mathrm{Ti}$ phase.

う。しかし, N/Ti比による残留応力の変化が, 必ずし あ格子定数の変化のみにもとづくだけでなく，化学量論 值からのずれにより, 皮膜中に導入されるボイド ${ }^{15)}$ 等の 欠宿が応力緩和につながっていることあ考えられる。

\section{3. $3 \mathrm{TiN及び} \alpha$-Ti存在下における残留応力}

図 6 にN/Ti比 $=0.7 \sim 0.4$ の皮膜の代表的な X線回折 図形を示す。 $\mathrm{N} / \mathrm{Ti}$ 比 $=0.7$ 前後で $\mathrm{Ti}{ }_{2} \mathrm{~N}$ の析出がはじま り, $\mathrm{TiN}$ と $\mathrm{Ti}_{2} \mathrm{~N}$ の混合組織となる。 $\mathrm{N} / \mathrm{Ti}$ 比 $=0.62$ の皮 膜では $\alpha-\mathrm{Ti}$ 相の析出がみられ, $\mathrm{TiN}, \mathrm{Ti}_{2} \mathrm{~N}, \boldsymbol{\alpha}-\mathrm{Ti}$ の 3 相が共存する皮膜となり, N/Ti比 $=0.56$ 以下では $\mathrm{Ti}_{2} \mathrm{~N}$ と $\alpha-\mathrm{Ti}$ の 2 相となる。 $\alpha-\mathrm{Ti}$ 相の析出は, 既報 ${ }^{8)}$ に比べ若干大きいN/Ti比でみられるが，これは基板材 料の相違等によるものと思われる。

TiN以外の相の生成によって, 皮膜の残留応力は図 7 のような変化を示す。 $\mathrm{Ti}_{2} \mathrm{~N}$ の析出によって, N/Ti比= 0.8 付近のTiN単相皮膜に比べ, 残留応力は増加する傾 向がみられる。しかし $\alpha$-Ti相の析出によって残留応力 に明瞭な低下がみられる。X線回折の結果から $\alpha$-Ti相 の回折強度が強く得られる $\mathrm{N} / \mathrm{Ti}$ 比 $=0.41$ の皮膜では, あはや圧縮の残留応力は示さず $0.2 \mathrm{GPa}$ の引張り残留応 力を示す。この引張り残留応力は，シリコン基板と $\mathrm{Ti}$ 皮膜の熱膨張係数の差に基づく熱応力に相当するすのと 考えられる。

このような, $\mathrm{Ti}_{2} \mathrm{N及び} \alpha$ - $\mathrm{Ti}$ 相生成による残留応力の 変化は, 皮膜構造に関係する皮膜硬度の变化に基づくも のと推測される。本実験におけるTiN皮膜の硬度は, TiN単相皮膜では2 $2500 \mathrm{Hv}$ 前後の值を示したが， $\mathrm{Ti}_{2} \mathrm{~N}$ の 


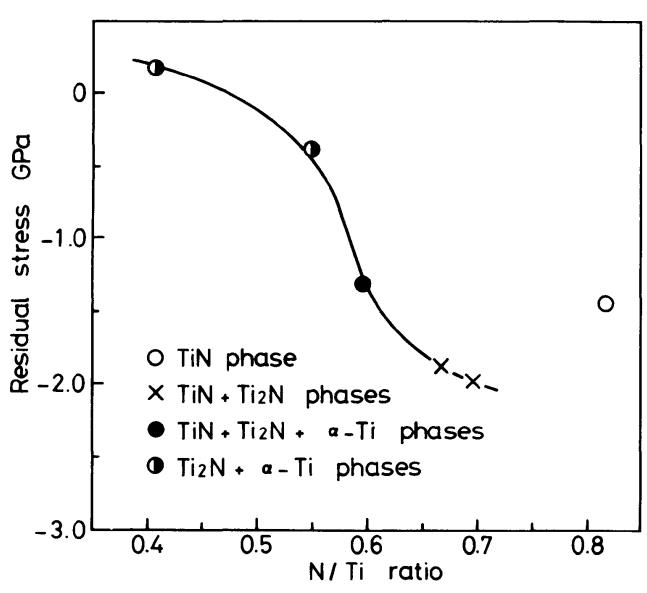

Fig. 7 Effect of $\mathrm{N} / \mathrm{Ti}$ ratio on residual stress in $\mathrm{Ti}-\mathrm{N}$ film containing $\mathrm{Ti}_{2} \mathrm{~N}$ and $\alpha$-Ti phase.

析出により皮膜硬度は上昇し $/ \mathrm{Ti}$ 比 $=0.67$ で $3100 \mathrm{Hv}$ を 示した。一方， $\alpha$-Tiの生成により硬度の低下がみられ， $\mathrm{N} / \mathrm{Ti}$ 比 $=0.41$ で1600Hvであった。これらのことは, そ れぞれの残留応力の增加ならびに減少に対応する。すな わち, 皮膜の塑性変形の難易が, 応力緩和の程度に結び ついているすのと考えられる。

以上のように, Ti-N皮膜のGPaオーダーの圧縮残留 応力值は皮膜の組成, 構造, 硬度に影響されることがわ 加る。

\section{4 酸素及ひ炭素添加の堁}

酸素や炭素はTiN皮膜の色調等の改質を目的とした添 加元素として用いられており，それらの残留応力に及ぼ す影響に興味が持たれている(6)。

图 8 に，バイアス電圧 $-200 \mathrm{~V} て ゙ （ \mathrm{~N} \mathrm{at} \%+\mathrm{O}$ at \% ) /Ti at\%の比がほぼ 1 になるように作製17)した酸素濃 度の異なるTiN皮膜の残留応力の变化を示す。皮膜中の 酸素濃度の增加に伴い圧縮残留応力の明瞭な增加がみら

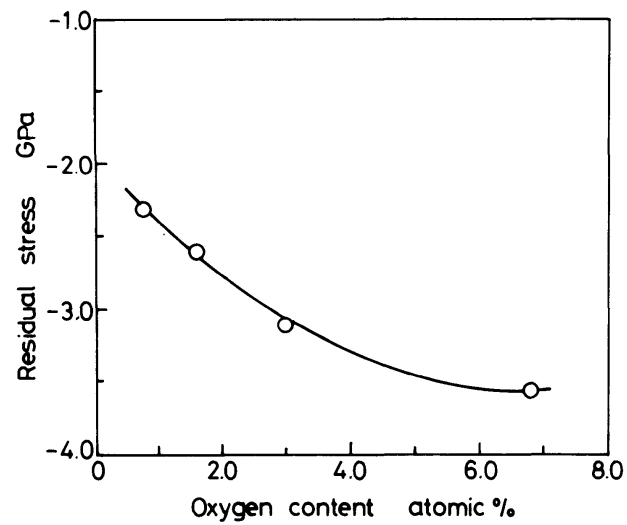

Fig. 8 Effect of oxygen contents on residual stress in Ti$\mathrm{N}$ film.
Table 1 Effect of carbon contents on residual stress in Ti-N film.

\begin{tabular}{c|c}
\hline $\begin{array}{c}\mathrm{Ti}_{1-A} \mathrm{C}_{\mathrm{X}} \mathrm{N}_{\mathrm{Y}} \mathrm{O}_{2} \\
(\mathrm{~A}=\mathrm{X}+\mathrm{Y}+\mathrm{Z})\end{array}$ & Residual stress $(\mathrm{GPa})$ \\
\hline $\mathrm{Ti}_{0.49} \mathrm{C}_{0} \mathrm{~N}_{0.50} \mathrm{O}_{0.01}$ & -2.5 \\
\hline $\mathrm{Ti}_{0.59} \mathrm{C}_{0.06} \mathrm{~N}_{0.34} \mathrm{O}_{0.01}$ & -2.6 \\
\hline $\mathrm{Ti}_{0.57} \mathrm{C}_{0.09} \mathrm{~N}_{0.33} \mathrm{O}_{0.01}$ & -3.2 \\
\hline $\mathrm{Ti}_{0.53} \mathrm{C}_{0.09} \mathrm{~N}_{0.37} \mathrm{O}_{0.01}$ & -3.5 \\
\hline
\end{tabular}

れ，負バイアス電圧印加のもとで取り込まれた酸素 ${ }^{18)}$ は, TiN皮膜の圧縮残留応力を増加させることがわかる。

同様に皮膜中に炭素を添加した場合（表 1 ）, 炭素濃 度の增加により圧縮残留応力は增加する。

酸素の添加による残留応力の增加は, 酸素が皮膜の体 積を膨張するように取り込まれたこと，さらに酸素添加 による皮膜硬さの増加 ${ }^{17)}$ な゙に起因しているものと推測 される。また, 炭素濃度の増加による残留応力の増加は, TiN 中の炭素の固溶による格子定数の増加 ${ }^{19}$ に対応し ていると考えられる。

\section{4. 結言}

シリコンウェハ上に形成させた, 種々の組成（N/Ti 比 $=0.41 \sim 1.09$, 酸素濃度 $=0.8 \sim 6.5 \mathrm{at} \%$, 炭素濃度 $=$ 5.7～9. 4at\%）を有するTi-N皮膜の残留応力を基板の 変形量から求め, 残留応力に及ぼす皮膜組成の影響を検 討した。その結果は以下のようであった。

1) $\mathrm{TiN}$ 単相皮膜の圧縮残留応力はN/Ti比 $=1$ 付近で 最大値を示し, N/Ti比が 1 より增加しても減少しても 残留応力は減少した。

2) $\mathrm{Ti}_{2} \mathrm{~N}$ 相の生成により圧縮残留応力の増加がみられ るが， $\alpha$-Ti相の生成により圧縮残留応力は減少し, $\mathrm{N}$ $/ \mathrm{Ti}$ 比 $=0.41$ の皮膜では, 引張り残留応力を示した。

3 ）皮膜中の酸素及び炭素濃度の増加により圧縮残留応 力の増加が認められた。

\section{解 辟}

本研究にあたり大变有意義なご助言を睗わりました東 洋大学・柏木邦宏助教授, ならびに大阪府立大学・中山

豊教授に深く感謝致します。また，膜厚測定にご協力 頂きました湖東京精密 ・ 大柳和彦, 渡辺 均の両氏に謝 意を表します。

(1988-10-31 受理)

\section{文献}

1) S. Kanamori ; Thin Solid Films, 136, 195 (1986)

2 ) 鈴木 寿, 松原秀彰, 松尾 明, 渋木邦夫; 日本金属学会 誌, 49, 773 (1985)

3 ) L. Chollet, A. T. Perry ; Thin Solid Films, 123, 223 (1985) 
4 ）西田典秀, 川崎仁士, 本田和男, 細川智生 ; 金属表面技術, 37,346 (1986)

5 ）稲川幸之助, 渡辺一弘, 田中一郎, 斉藤一也, 伊藤昭夫 ; 金属表面技術協会第69回講演大会講演要旨集, p. 60（1984）

6) C. T. Wu ; Thin Solid Films, 64, 103 (1979)

7 ) 学術振興会編 ; 薄膜ハンドブック,p. 338 (オーム社, 1983)

8 ）西田典秀, 川崎仁士, 本田和男, 細川智生 ; 金属表面技術, 38, 483 (1987)

9 ) 戸谷恒夫, 加藤昭実, 榎本祐哃 ; 真空, 25, 75 (1982)

10) R. Glang, R. A. Holmwood, R. L. Rosenfeld ; Rev. Sci. Instrum., 36, 7 (1965)

11）飯田修一 他編；新版物理定数表, p. 24（朝倉書店, 1984）

12) L. E. Toth ; Transition Metal Carbides and Nitrides (Academic Press, N. Y., 1971)
13）大平重男, 日江井香弥子 ; 金属表面技術協会第75回講演大 会講演要旨集, p. 202（1987）

14）梶尾 秀, 川下安司；金属表面技術協会第75回講演大会講 演要旨集, p. 90 (1988)

15) J. E. Sundgren, B. E. Jacobson, M. K. Hibbs ; $Z$. Metallkde, 75, 11 (1984)

16）岸 松雄, 渡辺 昭, 下山良造 ; 金属表面技術, 35, 50 (1984)

17）西田典秀, 川崎仁士，本田和男，細川智生；金属表面技術, 39, 539 (1988)

18）西田典秀, 川绮仁士，本田和男，細川智生；金属表面技術, 37, 346 (1986)

19) Pol Duwez and Francis Odell; J. Electrochem. Soc., 97, 299 (1950) 